\title{
KEGIATAN ORGANISASI SAYAP PARTAI POLITIK YANG BERTENTANGAN DENGAN UUD 1945 SEBAGAI ALASAN PEMBUBARAN PARTAI POLITIK OLEH MAHKAMAH KONSTITUSI
}

(Activities Against Constitution by Political Party Underbow Organization as Reason for The Dissolution of Political Party by The Constitutional Court)

\author{
Ibnu Sina Chandranegara; Merdiansa Paputungan \\ Fakultas Hukum Universitas Muhammadiyah Jakarta \\ ibnusinach@umj.ac.id
}

Tulisan Diterima: 05-12-2019; Tulisan Direvisi: 06-03-2020; Disetujui Diterbitkan: 09-03-2020

DOI: http://dx.doi.org/10.30641/dejure.2020.V20.117-136

\begin{abstract}
This paper intends to analysis relationship between political parties and their Underbouw organizations. The relationship is related to legal liability on violation by Underbouw organization to the provisions of Article 40 of Political Party Law, especially in the case of the dissolution of political parties. This paper is focused on answering two questions (1) What is legal relationship between political parties and Underbouw organization; (2) does legal liability for Underbouw organization is related to responsibility of political party in the case of the dissolution of political parties,. This research using normative approach to determine the dissolution of political parties. This study concludes, first, the legal relationship between the Underbouw Organization and Political Parties is in the same legal entity. In this context, the Underbouw Organization is a non-legal entity organization under (in structure) and belongs to a Political Party. Secondly, the right mechanism for the Underbouw Organization is the same as the mechanism that applies to the political parties themselves. So that when the Underbouw Organization violates the rules regulated in Article 40 of the Political Party Law, the mechanism and sanctions that apply are as stipulated in Articles 47, 48, up to Article 49 Political Party Law.
\end{abstract}

Keyword: political party underbouw organizations, legal responsibility, political party dissolution

\begin{abstract}
ABSTRAK
Tulisan ini hendak melakukan analisis yuridis terhadap hubungan antara Partai Politik dan Organisasi Sayap Parpol-nya (OSP). Hubungan dimaksud adalah berkenaan dengan pertanggungjawaban hukum apabila terjadi pelanggaran oleh organisasi sayap parpol khususnya dalam hal pembubaran partai politik. Tulisan ini difokuskan untuk menjawab dua pertanyaan, yakni: (1) Bagaimanakah hubungan antara partai politik dengan organisasi sayap partai politik?; (2) Apakah kegiatan OSP yang bertentangan dengan UUD 1945 dapat dimaknai luas dan berdampak terhadap partai politik khususnya dalam sebagai alasan pembubaran partai politik. Metode yang digunakan dalam penelitian ini adalah penelitian hukum normatif. Pendekatan normatif digunakan untuk mengetahui hubungan hukum dan pertanggung jawaban OSP terkait pembubaran partai politik. Penelitian ini mengambil kesimpulan, Pertama, hubungan hukum antara OSP dan Partai Politik adalah dalam satu entitas hukum (subyek hukum) yang sama. OSP merupakan organisasi bukan badan hukum yang berada di bawah (dalam struktur) dan milik Partai Politik. Kedua, bahwa kegiatan OSP yang bertentangan dengan UUD 1945 dapat menjadi alasan pembubaran partai politik di Mahkamah Konstitusi. Sehingga ketika OSP melakukan pelanggaran sebagaimana yang diatur dalam Pasal 40 UU Partai Politik, maka mekanisme dan sanksi yang berlaku adalah sama dengan mekanisme penjatuhan sanksi sebagaimana diatur dalam Pasal 47, 48, sampai dengan Pasal 49 UU Partai Politik.
\end{abstract}

Kata kunci: organisasi sayap partai politik, pertanggungjawaban hukum, pembubaran partai politik 


\section{PENDAHULUAN}

Kehadiran partai politik dalam kehidupan negara yang menganut prinsip demokrasi adalah hal yang hampir mustahil untuk ditiadakan. Bahkan menurut S.C. Stokes, 'Political parties created democracy', partai politiklah yang membentuk demokrasi, bukan sebaliknya. ${ }^{1}$ Oleh sebab itu, partai politik merupakan pilar yang perlu bahkan sangat penting untuk diperkuat derajat perlembagaannya (the degree of institutionalization) dalam setiap sistem politik yang demokratis. Derajat perlembagaan partai politik itu sangat menentukan kualitas demokrasi kehidupan politik suatu negara. ${ }^{2}$ Sejalan dengan hal tersebut, R.H. Soltau mendefinisikan partai politik sebagai sekelompok warga negara yang sedikit banyak terorganisir, yang bertindak sebagai suatu kekuatan politik dan yang dengan memanfaatkan kekuasaannya untuk memilih, bertujuan menguasai pemerintahan dan melaksanakan kebijaksanaan umum mereka. ${ }^{3}$

Secara konstitusional, setelah UUD 1945 mengalami 4 (empat) kali amandemen, maka kedudukan dan eksistensi partai politik telah mendapatkan 'rumah' di dalam konstitusi. Secara spesifik, rumah tersebut terdapat dalam Pasal 28E ayat (3) UUD 1945 yang menentukan: "Setiap orang berhak atas kebebasan berserikat, berkumpul, dan mengeluarkan pendapat". Akan tetapi menurut Jimly Asshiddiqie, ${ }^{4}$ adanya jaminan konstitusional dalam Pasal 28E ayat (3) UUD 1945, memang tidak menghilangkan keperluan akan pengaturan lebih lanjut pelaksanan hak-hak itu dengan undang-undang seperti dimaksud oleh Pasal 28 UUD 1945. Dalam pelaksanaannya itu, harus diingat pula adanya pengaturan pembatasan hak asasi manusia seperti yang dimaksud oleh Pasal 28J ayat (2) UUD 1945. Pengaturan tersebut teramat penting dalam sebuah negara hukum yang demokratis seperti Indonesia, agar jalannya kehidupan bernegara tidak berubah menjadi demokrasi yang kebablasan. Terlebih jika melihat

$1 \quad$ S. C. Stokes, "Political Parties And Democracy", Annual Review Political Science 18, No 2 (1999), 243 Jimly Asshiddiqie, Pokok-Pokok Hukum Tata Negara Indonesia, (Jakarta: PT. Bhuana Ilmu Populer 2007), 710.

3 Miriam Budiajo, Pengantar Ilmu Politik, Jakarta: Gramedia, (2000), 162.

4 Jimly Asshiddiqie, Kemerdekaan Berserikat, Pembubaran Partai Politik Dan Mahkamah Konstitusi, (Jakarta: Konstitusi Press, 2006), 10. fungsi dari partai politik dalam kehidupan sebuah negara yang demokratis. ${ }^{5}$ Sebagai pilar utama demokrasi, partai politik mempunyai fungsi yang sangat penting, di antaranya: (1) sarana komunikasi politik, ${ }^{6}(2)$ sarana sosialisasi politik, ${ }^{7}(3)$ sarana rekruitmen politik, ${ }^{8}(4)$ sarana pengatur konflik (conflict management). ${ }^{9}$ Keempat fungsi partai politik di atas, kemudian dijabarkan menjadi tujuan dan fungsi partai politik dalam Undang-Undang (Selanjutnya disebut UU) Nomor 2 Tahun 2008 tentang Partai Politik. Di saat yang bersamaan, Undang-Undang Nomor 2 Tahun 2008 juga menentukan bahwa Partai Politik memiliki hak, yang diatur dalam Pasal 12. Di antara hak yang dimiliki oleh Partai Politik tersebut adalah hak untuk membentuk dan memiliki organisasi sayap partai politik. Akan tetapi hak ini tidak diikuti dengan pengaturan lebih lanjut dalam Pasal-Pasal selanjutnya, maupun peraturan dibawahnya. ${ }^{10}$

Pengaturan yang tidak memadai tentang organisasi sayap partai politik bukan tanpa permasalahan dari sisi hukum. Permasalahan tersebut terutama berkenaan dengan hubungan

5

Muhammad Reza Winata, Politik Hukum Dan Konstitusionalitas Kewenangan Pembubaran Organisasi Kemasyarakatan Berbadan Hukum Oleh Pemerintah, Jurnal Penelitian Hukum De Jure 18, No. 4 , (2018), 446

6 Salah satu tugas dari partai politik adalah menyalurkan aneka ragam pendapat dan aspirasi masyarakat dan mengaturnya sedemikian rupa sehingga kesimpangsiuran pendapat dalam msayarakat berkurang. Widayati, "Pembubaran Partai Politik Dalam Sistem Ketatanegaraan Indonesia”, Jurnal Hukum, Vol. XXVI, No. 2, Agustus (2011), 619-620.

7 Sosialisasi politik diartikan sebagai proses melalui mana seseorang memperoleh sikap dan orientasi terhadap fenomena politik, yang umumnya berlaku dalam masyarakat di mana ia berada. Proses sosialisasi politik diselenggarakan melalui ceramah-ceramah penerangan, kursus kader, kursus penataran, dan sebagainya. ibid

8 Partai politik juga berfungsi untuk mencari dan mengajak orang yang berbakat untuk turut aktif dalam kegiatan politik sebagai anggota partai (political recruitment). Dengan demikian, partai turur memperluas partisipasi politik. ibid

9 Dalam suasanan demokrasi, persaingan dan perbedaan pendapat dalam masyarakat merupakan soal yang wajar. Jika sampai terjadi konflik, partai politik berusaha untuk mengatasinya. ibid

10 Budi Hermawan Bangun, Perbandingan Sistem Dan Mekanisme HAM Negara-Negara Anggota ASEAN: Tinjauan Konstitusi Dan Kelembagaan, Jurnal Penelitian HAM 10, No. 1, (2019), 101 
antara partai politik dengan organisasi sayapnya. Sebagaimana diketahui, organisasi sayap partai politik adalah sama dengan organisasi pada umumnya, yakni memiliki struktur, serta memiliki program dan kegiatan yang hendak dilakukan. Umumnya organisasi sayap Partai politik memang dibentuk untuk mendulang suara partai politik pada segmen yang spesifik. Sebagai contoh misalnya, banyak Parpol yang berhaluan nasionalis, membantuk organisasi sayap yang menyasar segmen pemilih umat Islam. Sebut saja misalnya Partai Demokrasi Perjuangan (PDI-P) memiliki Baitul Muslimin Indonesia (Bamusi), Partai Gerindra memiliki Gerakan Muslim Indonesia Raya (Gemira), Partai Demokrat mempunyai Majelis Dzikir SBY, demikian pula Partai Golongan Karya (Golkar) mendirikan Majelis Dakwah Islamiyah (MDI) untuk jamaah pria dan dan Al-Hidayah untuk jamaah perempuan. ${ }^{11}$

Pentingnya mendudukkan hubungan antara partai politik dengan organisasi sayapnya, karena di dalam UU Nomor 2 Tahun 2008 Juga diatur tentang larangan bagi partai politik dalam Pasal 40 dan sanksi bagi Partai Politik apabila melanggar larangan dalam Pasal 48. Sebagai sebuah organisasi, organisasi sayap partai politik dengan struktur, kepengurusan, serta program kerja yang dimiliki, memiliki kemampuan untuk melakukan larangan yang diatur dalam Pasal 40 UU No. 2 Tahun 2008. Hal ini menjadi persoalan, terutama bagi partai politik itu sendiri. Karena secara yuridis, organisasi sayap parpol merupakan organisasi yang berada langsung di bawah Partai Politik. Sehingga konstruksi yang demikian itu lekat kaitannya dengan alasan pembubaran partai politik yang ditentukan secara limitatif menurut peraturan perundang-undangan.

Undang-undang mengatur pembubaran partai dapat dilakukan hanya melalui dua inisiatif. Pertama, inisiatif internal. Keinginan membubarkan berasal dari dalam partai sendiri. Bentuknya bisa berupa keputusan internal partai untuk membubarkan diri atau menggabungkan diri ke partai lain. Kedua, inisiatif eksternal. Partai dibubarkan oleh Mahkamah Konstitusi (MK). Alasan pembubaran partai melalui MK bersifat

11 Ahmad Asroni, Muhammad Yusup, dan Adib Sofia, "Dakwah Dan Politik: Menakar Kontribusi Organisasi Islam Sayap Partai Politik Bagi Masyarakat Muslim Yogyakarta”, Jurnal Dakwah, Volume XIV, No 1, (2013), 29. limitatif. Ketentuannya terdapat dalam Pasal 40 Ayat 2 dan Pasal 40 Ayat 5. Partai dilarang melakukan kegiatan yang bertentangan dengan UUD 1945 dan peraturan perundang-undangan. Selain itu, partai juga tidak diperbolehkan menggelar kegiatan yang membahayakan keutuhan dan keselamatan NKRI. Selanjutnya, partai dilarang menganut, mengembangkan, dan menyebarkan paham komunisme/marxismeleninisme. Limitasi larangan inilah yang menurut bahasa undang-undang menjadi batasan/alasan untuk membubarkan partai tanpa inisiatifnya sendiri. Tulisan ini dimaksudkan untuk menjawab apakah kegiatan organisasi sayap partai dapat dimaknai luas sebagai kegiatan partai apabila dikaitkan dengan alasan pembubaran partai politik.

\section{METODE PENELITIAN}

Penelitian ini merupakan penelitian hukum dengan menggunakan pendekatan normatif dan sejarah hukum. Salah satu kegunaan dari penelitian hukum adalah untuk mengetahui apakah dan bagaimanakah hukum mengatur suatu hal serta bagaimana aturan hukum tersebut diterapkan. ${ }^{12}$ Sumber data dalam penelitian ini adalah sumber data sekunder yang terdiri dari bahan hukum primer, bahan hukum sekunder dan dan bahan hukum tersier. Bahan hukum primer dalam penelitian ini mencakup peraturan perundang-undangan bidang kepartaian khususnya terkait dengan organisasi sayap partai politik. Adapun bahan hukum sekunder terdiri dari literatur, majalah tulisan ilmiah, maupun artikel tentang pembubaran partai politik di beberapa negara, sedangkan bahan hukum tersier adalah bahan yang menjelaskan bahan primer dan bahan sekunder yang terdiri dari kamus, kamus hukum dan sebagainya.

Teknik analisis dilakukan dengan dua metode pendekatan, pertama, pendekatan normatif yang digunakan untuk mengetahui pembubaran partai

12 Menurut Sunaryati Hartono, metode penelitian hukum normatif memiliki beberapa kegunaan, di antaranya adalah mengetahui atau mengenal apakah dan bagaimanakah hukum positifnya mengenai suatu masalah tertentu, serta juga untuk mencari asas hukum, teori hukum, dan sistem hukum. Lihat Sunaryati Hartono, Penelitian Hukum Di Indonesia Pada Akhir Abad Ke-2o, (Bandung: Alumni, 1994), 140- 141. 
politik sesuai dengan ketentuan hukum yang berlaku dan praktik pelaksanaannya, baik berupa keputusan administratif maupun keputusan pengadilan. Kedua, pendekatan sejarah hukum meliputi sejarah norma hukum dan penerapan norma hukum. ${ }^{13}$ Pendekatan sejarah digunakan dalam penelitian yang tidak hanya menekankan pada waktu tertentu tetapi untuk memahami masa lalu. Hal itu membutuhkan penafsiran atas fakta-fakta yang diketahui dari bahan-bahan sejarah. Dokumen-dokumen yang akan dianalisis merupakan pintu masuk untuk mengkontruksikan kembali apa yang terjadi pada masa lalu sesuai dengan konteksnya saat itu. ${ }^{14}$

Penelitian dan pengkajian khususnya tentang pembubaran partai politik telah dilakukan oleh beberapa penulis, antara lain: Pertama, Mochamad Ali Safa'at dalam Disertasi yang berjudul Pembubaran Partai Politik di Indonesia: Analisis Pengaturan Hukum dan Praktik Pembubaran Partai Politik 1959-2004. Dalam disertasinya analisa terhadap ketentuanketentuan konstitusi yang digunakan sebagai landasan pembubaran partai politik di masa lalu. Selain itu, memberikan beberapa masukan bagi perkembangan demokrasi bangsa ke depan berkenaan dengan hak berserikat, berkumpul dan mengeluarkan pendapat yang disalurkan dalam sebuah wadah yang disebut sebagai partai politik. ${ }^{15}$ Kedua, Jimly Asshiddiqie menulis buku tentang Kemerdekaan Berserikat, Pembubaran Partai Politik dan Mahkamah Konstitusi. Dalam buku tersebut, penulis menganalisa tentang kebebasan untuk berserikat dan berkumpul, reformasi partai politik, dan kewenangan Mahkamah Konstitusi dalam melakukan pembubaran partai politik. ${ }^{16}$ Ketiga, Sri Hastuti Puspitasari, dkk, pernah menulis tentang Urgensi Perluasan Permohonan Pembubaran Partai Politik di Indonesia. Dalam tulisan tersebut disimpulkan bahwa dengan dilakukannya perluasan terhadap permohonan pembubaran partai politik, secara sadar negara

\footnotetext{
13 Ibid, hal. 144.

14 Earl Babbie, The Practice of Social Research, Belmont: Wadsworth Publising Company, (1998), 325 dan 328 - 329.

15 Mochamad Ali Safa'at, Pembubaran Partai Politik Di Indonesia: Analisis Pengaturan Hukum dan Praktik Pembubaran Partai Politik 1959 - 2004, (Jakarta: Disertasi FH UI, 2009)

16 Jimly Asshiddiqie, Kemerdekaan Berserikat, Pembubaran Partai Politik....Op.Cit.
}

Indonesia telah melangkahkan kakinya ke arah sistem pemilu yang lebih demokratis. ${ }^{17}$ Namun yang membedakan artikel ini dengan penelitian sebelumnya adalah terhadap objek penelitiannya yang berfokus kepada organisasi sayap partai politik dan kaitannya dengan pembubaran partai politik.

\section{PEMBAHASAN DAN ANALISIS}

\section{A. Alasan Pembubaran Partai Politik di Indonesia}

Pembubaran Partai Politik di Indonesia dalam sejarah ketatanegaraan Indonesai bisa dikatakan sejak masa demokrasi terpimpin pada tahun 1959 dengan dikeluarkannya Dekrit Presiden 5 Juli 1959. Hal ini sebetulnya sudah dapat dilihat pada tanggal 28 Oktober 1956, Soekarno di depan pertemuan wakil-wakil pemuda dari semua partai politik menyatakan bahwa kondisi bangsa pada saat itu bertentangan dengan makna Sumpah Pemuda 28 Oktober 1928. Soekarno melihat bahwa bangsa Indonesia saat itu terpecah belah bukan hanya oleh rasa kesukuan dan kedaerahan akan tetapi oleh kepartaian yang menjadi penyakit yang lebih hebat dari rasa kesukuan dan kedaerahan. ${ }^{18}$ Pada waktu itu partai politik berjumlah sekitar 40 partai politik. Pada tanggal 31 Desember 1959, Presiden Soekarno mencabut maklumat wakil presiden tanggal 3 November 1945 dan menggantikannya dengan Penetapan Presiden No. 7 tahun 1959 tentang Syarat-syarat Penyederhanaan Kepartaian yang pelaksanaannya diatur di dalam Peraturan

17 Sri Hastuti Puspitasari, Zayanti Mandasari, Harry Setya Nugraha, "Urgensi Perluasan Permohonan Pembubaran Partai Politik di Indonesia", Jurnal Hukum Ius Quia Iustum No. 4 Vol. 23, (2016): 552 575

18 Soekarno juga mengecam Maklumat Wakil Presiden 3 November 1945 yang membuka jalan pembentukan partai-partai politik secara bebas. Menurut dia, partai politik tidak berbeda dengan penyakit yang lebih parah dari fanatisme kesukuan dan kedaerahan sehingga satu dengan yang lainnya saling menginjak. Untuk itu Soekarno menyarankan agar para pemimpin partai politik berunding dan memutuskan untuk mengubur partai politik. Penguburan partai politik dimaksudkan untuk menyehatkan kondisi politik karena jumlah partai politik dinilai sudah terlalu banyak dan membuat pemerintahan tidak berjalan sebagaimana mestinya dan menghambat pembangunan nasional. William R. Liddle, Partisipasi \& Partai Politik Indonesia pada Awal Orde Baru, (Jakarta: Pustaka Utama Grafiti, 1992), 112. 
Presiden Nomor 13 tahun 1960 tentang Pengakuan, Pengawasan, dan Pembubaran Partai-Partai. Di dalam pasal 9 ayat (1) Penetapan Presiden No. 7 tahun 1959 dijelaskan bahwa Presiden setelah mendengar pendapat dari Mahkamah Agung dapat melarang dan/atau membubarkan partai yang: (1) Bertentangan dengan azas dan tujuan Negara; (2) Programnya bermaksud untuk merombak azas dan tujuan negara; (3) Sedang melakukan pemberontakan karena pemimpin-pemimpinnya turut serta dalam pemberontakan-pemberontakan atau jelas memberikan bantuan, sedangkan partai itu tidak dengan resmi menyalahkan perbuatan anggota anggotanya; (4) tidak memenuhi syaratsyarat lain yang ditentukan dalam Penetapan Presiden ini.

Mekanisme pelarangan dan/atau pembubaran partai politik terdapat di dalam Pasal 6 sampai Pasal 8 Peraturan Presiden Nomor 13 tahun 1960 tentang Pengakuan, Pengawasan, dan Pembubaran partai-partai. Mekanismenya sebagai berikut: Pertama, Presiden menyerahkan suratsurat dan alat bukti yang lain kepada Mahkamah Agung sebagai alat pembuktian terhadap suatu partai politik apabila Presiden merasa bahwa terdapat suatu partai politik yang dianggap berada dalam kondisi sebagaimana yang dijelaskan di dalam Pasal 9 ayat (1) Penetapan Presiden No. 7 tahun 1959. Kedua, Mahkamah Agung memeriksa persoalan yang diajukan oleh Presiden secara yuridis dan obyektif dengan mengadakan pemeriksaan dengan acara bebas. Ketiga, dalam pemeriksaan, Mahkamah Agung dapat mendengar keterangan saksi-saksi dan ahli-ahli di bawah sumpah. Keempat, hasil pemeriksaan Mahkamah Agung diberitahukan kepada Presiden. Kelima, setelah meneriman pertimbangan Mahkamah Agung, Presiden mengeluarkan Keputusan Presiden yang menyatakan pembubaran suatu partai yang secepat mungkin diberitahukan kepada pimpinan partai tersebut. Keenam, dalam jangka waktu 30 hari sejak tanggal berlakunya Keputusan Presiden tersebut, pimpinan partai yang dimaksud harus menyatakan partainya bubar dan memberitahukannya kepada Presiden seketika itu juga. Ketujuh, apabila tenggang waktu tersebut lewat tanpa ada pernyataan bubar dari partai yang dimaksud, maka partai tersebut merupakan perkumpulan terlarang. Kedelapan, sebagai akibat hukum pembubaran/pelarangan suatu partai, maka anggota partai yang dimaksud yang menjadi anggota MPR, DPR, dan DPRD secara otomatis dianggap berhenti sebagai anggota badan-badan tersebut.

Dengan dikeluarkannya aturan ini maka banyak partai yang dibubarkan oleh Pemerintah Soekarno. Salah dua partai terkenal yang dibubarkan oleh Soekarno yang pada waktu tahun 1955 termasuk partai yang mempunyai kursi di Parlemen dan Konstituante yaitu Partai Masyumi dan Partai Sosialis Indonesia. Partai Masyumi dibubarkan dengan Keputusan Presiden No. 200 tahun 1960 dan Partai Sosialis Indonesia dibubarkan dengan Keputusan Presiden No. 201 tahun $1960 .{ }^{19}$ Selain itu terdapat juga partai-

19 Pembubaran kedua partai ini dapat dilihat sebagai ujung dari konflik politik antara kedua partai tersebut dengan Presiden Soekarno dan partai pendukungnya terutama PKI. Masyumi merupakan salahsatupartai besardalam konstalasi perpolitikan Indonesia pada waktu itu dengan basis masa umat Islam dan juga memiliki dukungan yang paling luas di seluruh wilayah Indonesia. Masyumi memiliki pengaruh yang besar terhadap Pemerintahan Indonesiapadaawal kemerdekaan sampai tahun 50an. Masyumi masuk di dalam 4 besar pada pemilu 1955. Sedangkan PSI walaupun kurang memiliki dukungan masa, PSI merupakan partai yang memiliki pengaruh kuat karena tokoh-tokohnya yang dikenal sebagai cendekiawan dan teknokrat yang berperan besar dalam pembangunan. PSI pada pemilu 1966 hanya menempati urutan ke-8. Pada 21 Juli 1960 Soekarno memanggil pimpinan Masyumi dan PSI. Pemimpin Masyumi yang hadir pada waktu itu adalah Prawoto Mangkusasmito dan M. Yunan Nasution sedangkan pemimpin PSI yang hadir adalah Sutan Syahrir, Soebadio Sastrosatomo, dan T.A Murad. Dalam pertemuan selama sepuluh menit tersebut, Presiden Soekarno menyerahkan daftar pertanyaan yang harus dijawab pemimpin partai tersebut secara tertulis dalam waktu satu minggu. Jawaban dari kedua partai politik tersebut ternyata tidak memuaskan Presiden Soekarno, akhirnya pada 17 Agustus 1960 Presiden Soekarno mengeluarkan Keputusan Presiden Nomor 200 tahun 1960 yang membubarkan Masyumi dan Keputusan Presiden Nomor 201 tahun 1960 yang membubarkan PSI. Kedua Keputusan Presiden tersebut disampaikan kepada pimpinan masing - masing partai dengan pengantar dari Direktur Kabinet Presiden, Mr. Tamzil bertanggal 17 Agustus 196o. Dalam waktu 30x24 jam terhitung sejak tanggal berlakunya Keputusan Presiden tersebut yaitu tanggal 17 Agustus 1960, pimpinan Masyumi dan PSI diharuskan menyatakan partainya bubar dengan memberitahukan kepada Presiden. Hal itu sesuai dengan ketentuan Pasal 9 ayat (2) Penpres Nomor 7 tahun 1959 dan Pasal 8 ayat (2) Perpres Nomor 13 tahun 1960. Apabila dalam jangka waktu tersebut tidak dibubarkan, maka akan dinyatakan 
partai kecil yang ditolak pengakuannya yaitu Partai Syarikat Islam Indonesia (PSII)-Abikusno, Partai Rakyat Nasional (PRN)-Bebasa, Partai Rakyat Indonesia (PRI), dan Partai Rakyat Nasional (PRN)-Djody. ${ }^{20}$ Partai-partai ini ditolak pengakuannya dengan dikeluarkannya Keputusan Presiden Nomor 129 tahun 1961 oleh Presiden Soekarno. Terhadap Keputusan Presiden tersebut tidak terdapat upaya hukum yang dapat diajukan ke pengadilan. Kondisi tersebut dapat dipahami karena kekuasaan Presiden Soekarno pada waktu itu sangat besar, bahkan ketua Mahkamah Agung pun ditempatkan sebagai Menteri Koordinator Hukum dan Dalam Negeri yang kedudukannya di bawah Presiden. ${ }^{21}$

Pada era orde baru partai yang dibubarkan oleh Pemerintah Indonesia pada waktu itu adalah Partai Komunis Indonesia (PKI). PKI dibubarkan karena dianggap telah melakukan pembunuhan terhadap 6 Jenderal Angkatan Darat yang dikenal dengan nama peristiwa G30S/ PKI. Hal ini menimbulkan kekacauan politik pada waktu itu. Sebelumnya ketegangan antara TNI AD dengan PKI sudah dirasakan sejak era orde lama. Seperti pada kasus pemberontakan Pemerintan Revolusioner Indonesia/ Perjuangan

sebagai partai terlarang sebagaimana diatur di dalam Pasal 8 ayat (3) Perpres Nomor 13 tahun 1960. Alasan pembubaran tersebut dikarenakan keterlibatan Partai Masyumi dan PSI dalam PRRI. Hal ini tertulis di dalam konsideran "Menimbang" Keputusan Presiden tersebut. Pada 13 September 1960, pimpinan pusat Masyumi menyatakan Partai Masyumi bubar. Pernyataan tersebut dipandang lebih baik daripada bubar dengan sendirinya dan dinyatakan sebagai partai terlarang. Pilihan tersebut didasari oleh pertimbangan bahwa jika ditetapkan sebagai partai terlarang, maka akan berpotensi menimbulkan kesulitan dan bahaya yang lebih besar kepada anggota-anggotanya. Setelah Masyumi dan PSI dibubarkan, perjuangan tokoh-tokohnya dilakukan melalui Liga Demokrasi yang telah terbentuk sebelumnya yaitu 24 Maret 1960. Liga Demokrasi pada awalnya merupakan liga dari tokoh-tokoh partai dan organisasi yang anti komunis. Namun, akhirnya Liga Demokrasi ini juga dibubarkan pada Maret 1961 dengan alasan tidak sesuai dengan manipol. Eep Saefulloh Fatah. Catatan Politik 1998 - 1999 Eep Saefuloh Fatah; Menuntaskan Perubahan. (Jakarta: Mizan, 200o), 32.

20 Juniarto. Sejarah Ketatanegaraan Republik Indonesia, (Jakarta: Bumi Aksara, 1984), 24.

21 M. Rusli Karim. Perjalanan Partai Politik Di Indonesia; Sebuah potret pasang-surut, (Jakarta: Rajawali Press, 1993).
Rakyat Semesta (selanjutnya disebut PRRI/ Permesta), PKI menuduh bahwa TNI AD tidak bersungguh-sungguh menumpas pemberontakan yang terjadi. ${ }^{22}$ Di lain pihak, TNI AD menganggap selama ini PKI selalu melakukan pemberontakan atau kekacauan politik seperti yang terjadi di tiga daerah yaitu di Sumatra Selatan, Kalimantan Selatan, dan Sulawesi Selatan yang dikenal dengan nama "Peristiwa Tigas Selatan". ${ }^{23}$ Atas peristiwa tersebut, TNI AD menghentikan dan membekukan kegiatan PKI di beberapa daerah, serta menangkap dan memeriksa pimpinan PKI di daerah-daerah tersebut. Konflik politik seperti ini pun semakin lama semakin berlanjut dan tidak kunjung selesai. Setelah terbukti bahwa PKI merupakan dalang dari peristiwa G30S/PKI, Soeharto selaku staf Koti membekukan PKI dan organisasi masyarkatnya (ormas). Kebijakan ini dijalankan oleh para panglima di daerah. ${ }^{24}$ Selain itu, pada 12 November 1965 Pemerintah Indonesia mengeluarkan Instruksi Hankam Nomor 1015/65 tentang pembersihan personil yang terlibat atau terindikasi terlibat di dalam G30S/PKI.

Pada masa Pemerintahan Orde Baru PKI dibubarkan dengan dikeluarkannya Keputusan Presiden Nomor 1/3/1966. Keputusan Presiden ini dikeluarkan pada tanggal 12 Maret 1966 dengan dasar hukum yang digunakan adalah Surat Perintah 11 Maret 1966. Pembubaran PKI ini termasuk bagian-bagian organisasinya dari tingkat pusat sampai ke daerah beserta semua organisasi yang seasas atau berlindung di bawahnya serta pernyataan sebagai organisasi terlarang di seluruh wilayah Negara Kesatuan Republik Indonesia. Alasan pembubaran PKI menurut Keputusan Presiden tersebut adalah sebagai berikut:

1. Bahwa pada waktu akhir-akhir ini makin terasa kembali aksi-aksi gelap dilakukan oleh sisa-sisa kekuatan kontra-revolusi "Gerakan 30 September"/Partai Komunis Indonesia;

2. Bahwa aksi-aksi gelap itu berupa penyebaran fitnah, hasutan, desas-desus, adu domba, dan usaha peyusunan kekuatan bersenjata yang mengakibatkan tergangguya kembali keamanan rakyat dan ketertiban;

\section{Ibid, 33.}

23 Ibid, 34.

24 Ramly Hutabarat. Politik Hukum Pemerintahan Soeharto tentang Demokrasi Politik di Indonesia (1971-1997). (Disertasi Program Doktor Ilmu Hukum Pascasarjana Universitas Indonesia, 2002), 47 . 
3. Bahwa aksi-aksi gelap tersebut nyata-nyata membahayakan jalannya revolusi dewasa ini, khususnya penanggulangan kesulitan ekonomi dan pengganyangan proyek Nekolim "Malaysia";

4. Bahwa demi tetap terkonsolidasinya persatuan dan kesatuan segenap kekuatan progresip-revolusioner rakyat Indonesia yang anti feodalisme, anti kapitalisme, anti nekolim dan menuju terwujudnya masyarakat adil makmur berdasarkan Pancasila, masyarakat sosialisme Indonesia, perlu mengambil tindakan cepat, tepat, dan tegas terhadap Partai Komunis Indonesia.

Keputusan Presiden tersebut lalu dikukuhkan dengan Ketetapan MPRS/XXV/MPRS/1966 tentang Pembubaran Partai Komunis Indonesia, Pernyataan Sebagai Anggota Organisasi Terlarang Di Seluruh Wilayah Negara Republik Indonesia Bagi Partai Komunis Indonesia Dan Larangan Setiap Kegiatan Untuk Menyebarkan atau Mengembangkan Paham atau Ajaran Komunisme/ Marxisme-Leninisme.

Setelah tumbangnya Presiden Soeharto oleh kekuatan massa pada waktu dan era berganti dari era Orde Baru menjadi era Reformasi membuat kondisi perpolitikan di Indonesia berubah secara signifikan. Indonesia yang pada waktu itu hanya terdiri dari 2 partai dan 1 golongan rakyat berubah secara drastis. Partai politik bertambah banyak tanpa ada batasan dan kontrol dari pemerintah tidak seperti 2 era sebelumnya. Pada era Reformasi pengaturan mengenai partai politik diatur di dalam UU no. 2 tahun 1999. Undang-undang ini diundangkan sebelum dilakukannya amandemen UUD 1945. Di dalam UU no. 2 tahun 1999 tentang partai politik diatur juga mengenai pembubaran partai politik. Kewenangan pembubaran partai politik di dalam UU No. 2 tahun 1999 berada di tangan Mahkamah Agung. Mahkamah Agung dapat membekukan atau membubarkan partai politik apabila terbukti melanggar ketentuanketentuan yang diatur di dalam Pasal 17 ayat (2) UU no. 2 tahun 1999:

Dengan kewenangan yang ada padanya, Mahkamah Agung Republik Indonesia dapat membekukan atau membubarkan suatu Partai Politik jika nyata-nyata melanggar Pasal 2, Pasal 3, Pasal 5, Pasal 9, dan Pasal 16 undang-undang ini.
Di ayat selanjutnya dijelaskan bahwa pembubaran partai politik yang dilakukan oleh Mahkamah Agung berdasarkan putusan yang berkekuatan hukum tetap setelah mendengar dan mempertimbangkan keterangan dari pengurus pusat partai yang bersangkutan. Selain itu, juga dapat dilakukan melalui pengadilan terlebih dahulu yang berkaitan dengan pelanggaran yang dilakukan oleh partai politik yang menjadi dasar pembubaran partai politik. Sebelum pembubaran tersebut dilakukan, Mahkamah Agung memberikan peringatan tertulis sebanyak 3 kali berturut-turut dalam kurun waktu 3 bulan.

Pada masa berlakunya Undang-Undang Nomor 2 Tahun 1999 terdapat kasus gugatan pembubaran Partai Golkar di Mahkamah Agung, yaitu Perkara No. 01.G/WPP/2000 dan Perkara No. 02.G/WPP/2001. Perkara pertama diputus tidak dapat diterima, sedangkan perkara kedua diputus ditolak oleh Majelis Hakim. Selain itu, pada masa pemerintahan Presiden Abdurrahman Wahid pernah dikeluarkan Maklumat yang salah satu isinya adalah membekukan Partai Golkar sambil menunggu putusan MA. Namun Maklumat tersebut dinyatakan tidak memiliki kekuatan hukum mengikat oleh Ketetapan Nomor I/MPR/2001 setelah terdapat fatwa MA mengenai maklumat tersebut.

Setelah perubahan UUD 1945, dan lahirnya Mahkamah Konstitusi melalui Pasal 24 dan Pasal 24C UUD 1945, maka sejak saat itu pembubaran partai politik menjadi kewenangan Mahkamah Konstitusi. Pasal 68 sampai dengan pasal 73 UUD 1945 menegaskan segala tata cara pembubaran partai politik yang pada pokoknya memuat ketentuan sebagai berikut:

1. Pemohon pembubaran partai politik adalah pemerintah pusat:

2. Termohon tidak ditentukan secara eksplisit tetapi secara implisit, Termohonnya adalah partai politik yang diminta pemerintah untuk dibubarkan

3. Alasan pembubaran partai politik adalah bahwa ideologi, asas, tujuan, program, dan kegiatan partai politik yang dimohonkan dianggap bertentangan dengan UndangUndang Dasar 1945;

4. MK memberitahukan permohonan yang sudah diregistrasi kepada Termohon (partai politik terkait) dalam waktu 7 (tujuh) hari 
kerja sejak permohonan dicatat dalam Buku Registrasi Perkara Konstitusi (BRPK);

5. MK harus sudah memutus permohonan pembubaran partai politik dalam jangka waktu 60 (enam puluh) hari kerja sejak permohonan diregistrasi di BRPK;

6. Putusan MK tentang pembubaran partai politik ada 3 (tiga) kemungkinan;

a. Permohonan tidak dapat diterima jika permohonan tak memenuhi syaratsyarat sebagaimana dimaksud Pasal 68 Undang-Undang Mahkamah Konstitusi;

b. Permohonan tidak dikabulkan jika permohonan dinilai tidak beralasan; dan

c. Permohonan ditolak jika permohonan dinilai tidak beralasan.

7. Pelaksanaan putusan pembubaran partai politik dilakukan dengan membatalkan pendaftaran pada pemerintah, yang berarti sesuai dengan ketentuan Undang-Undang Partai Politik Tahun 2002 adalah pembubaran status badan hukumnya dan tidak diakui keberadaannya sebagai partai politik; dan

8. Putusan MKRI (Mahkamah Konstitusi Republik Indonesia) tentang pembubaran partai politik diberitahukan kepada partai politik yang bersangkutan dan diumumkan oleh pemerintah dalam Berita Negara Republik Indonesia dalam jangka waktu 14 (empat belas) hari kerja sejak putusan diterima.

\section{B. Alasan Pembubaran Partai Politik di beberapa negara}

Di Jerman, alasan pembubaran partai politik secara jelas dijabarkan pada Pasal 21 basic law yakni:

(a) Political parties shall participate in the formation of the political will of the people. They may be freely established. Their internal organisation must conform to democratic principles. They must publicly account for their assets and for the sources and use of their funds.

(b) Parties that, by reason of their aims or the behaviour of their adherents, seek to undermine or abolish the free democratic basic order or to endanger the existence of the Federal Republic of Germany shall be unconstitutional

(c) Parties that, by reason of their aims or the behaviour of their adherents, are directed to undermine or abolish the free democratic basic order or to endanger the existence of the Federal Republic of Germany shall be excluded from state funding. Has the exclusion been declared, tax advantages and other financial benefits for this party shall no longer be granted.

(d) The Federal Constitutional Court decides on the issue of unconstitutionality pursuant to paragraph 2 and on the exclusion of state funding pursuant to paragraph 3.

(e) The details are regulated by federal laws."

Pada ketentuan Pasal 21 ayat (1) basic law menyatakan bahwa "... Their internal organisation must conform to democratic principles...". Pasal 21 ayat (2) menjadi penekanan bahwa "Parties that, by reason of their aims or the behaviour of their adherents, seek to undermine or abolish the free democratic basic order or to endanger the existence of the Federal Republic of Germany shall be unconstitutional". Oleh karena itu, terhadap partai politik yang memiliki tujuan atau tindakan anggota atau pengikutnya berusaha untuk melemahkan atau menghapuskan tatanan dasar demokrasi yang bebas atau untuk membahayakan keberadaan Republik Federal Jerman akan dapat dibubarkan atau dinyatakan inkonstitusional oleh Bundesverfassungsgericht (Mahkamah Konstitusi Jerman). Ketentuan tersebut diperinci dengan adanya putusan pembubaran Nationaldemokratische Partei Deutschlands (NPD) yang memberikan kriteria terhadap ancaman yang menghapuskan tatanan demokrasi yang bebas dan keberadaan pemerintah Federal Jerman. Bahwa untuk melarang sebuah partai politik tidaklah cukup dengan tujuan partai politik diarahkan pada tatanan dasar demokrasi yang bebas. Sebaliknya, partai harus "mencari" untuk melemahkan atau menghapuskan tatanan dasar demokrasi yang bebas. dimana gagasan mencari membutuhkan perilaku aktif dari pengurus ataupun anggotanya. ${ }^{25}$

25 Partai ini umumnya digambarkan sebagai suatu organisasi neo-Nazi, dan tdisebut sebagai "partai neo-Nazi yang paling signifikan yang muncul setelah tahun 1945".Badan Federal Jerman 
Selain itu, diperlukan pula tindakan sistematis dari partai politik yang merupakan persiapan yang memenuhi syarat untuk melemahkan atau menghapuskan tatanan dasar demokrasi yang bebas atau bertujuan untuk membahayakan eksistensi Republik Federal Jerman, dengan adanya risiko khusus berupa indikasi yang spesifik dan berbobot yang menunjukkan bahwa setidaknya tindakan partai politik yang diarahkan pada tatanan dasar demokrasi yang bebas dari Republik Federal Jerman atau terhadap eksistensinya dapat berhasil. Penggunaan kekuatan menciptakan kawasan-kawasan yang dibatasi secara regional, terciptanya atmosfir ketakutan yang cenderung melemahkan dalam jangka panjang partisipasi yang bebas dan setara dari semua orang dalam proses pembentukan kemauan politik. Majelis hakim Bundesverfassungsgericht menjelaskan sebagaimana termuat pada putusan NPD $2 \mathrm{BvB}$ 1/13 bahwa: ${ }^{26}$ "In order to prohibit a political party, it is not sufficient that its aims are directed against the free democratic basic order. Instead, the party must "seek" to undermine or abolish the free democratic basic order.

1. The notion of seeking requires active behaviour un that respect. The prohibition of political party does not constitute a prohibition of views od ideology. In order to prohibit a political party, it is necessary that a party's actions amount to a fight against the free democratic basic order.

untuk Pendidikan Sipil, BPB, telah mengkritik NPD karena bekerja sama dengan anggota dari organisasi-organisasi yang kemudian dianggap inkonstitusional dan dibubarkan oleh pengadilan federal, sementara Kantor Federal Jerman untuk Perlindungan Konstitusi, atau Bundesamt für Verfassungsschutz, menggolongkan NPD sebagai suatu "ancaman terhadap tatanan konstitusional" berdasarkan platform dan filosofi yang diusung, oleh karenanya berada di dalam pengawasan mereka. Suatu upaya untuk melarang partai ini telah gagal pada tahun 2003, karena banyaknya agen dan informan pemerintah di dalam partai, beberapa di posisi tinggi, yang mana telah turut menulis sebagian dari bahan yang dipakai untuk menuntut mereka. Peter Davies, Derek Lynch, The Routledge Companion To Fascism And The Far Right, (London: Psychology Press, 2002), 315

26 Bundesverfassungsgericht, "Headnotes to the Judgement of the Second Senate of 17 January 2017 2BvB1/13-",https://www.bundesverfassungsgericht. de/SharedDocs/Entscheidungen/EN/2017/o1/ bs20170117_2bvboool1zen.html,diakses pada tanggal o8 Oktober 2019
2. It requires systematic action of the political party that amount to a qualified preparation for undermining or abolishing the free democratic basic order or aims at endangering the existence of the Federal Republic of Germany.

3. It is not necessary that this results in a specific risk to the goods protected under Art. 21 (2) GG. Yet it requires specific and weighty indications which suggest that it is at least possible that the political party's actions directed against the free democratic basic order of the Federal Republic of Germany or against its existense coulde be successful.

4. The use offorce is in itself a weighty indication justifying the assumption that action against the goods protected under Art. 21 (2) GG

Dari kutipan putusan tersebut dapat dilihat bahwa untuk membubarkan partai politik, tidaklah cukup bahwa tujuannya diarahkan pada tatanan dasar demokrasi yang bebas. Sebaliknya, partai politik harus secara nyata melemahkan atau menghapuskan tatanan dasar demokrasi yang bebas. Gagasan nyata membutuhkan perilaku aktif tanpa rasa hormat. Sehingga, pembubaran partai politik bukan hanya berdasarkan pada pandangan ideologi tetapi berdasarkan pada tindakan yang dilakukan partai adalah melawan tatanan demokrasi yang bebas. Diperlukan tindakan sistematis dari partai politik yang merupakan persiapan yang memenuhi syarat untuk melemahkan atau menghapuskan tatanan dasar demokrasi yang bebas atau bertujuan untuk membahayakan eksistensi Republik Federal Jerman. Tidak memerlukan resiko khusus terhadap ketentuan dalam Pasal 21 ayat (2) basic law, namun dibutuhkan indikasi yang spesifik dan berbobot yang menunjukkan bahwa setidaknya tindakan partai politik yang diarahkan bertentangan pada tatanan dasar demokrasi yang bebas dan terhadap keberadaan Republik Federal Jerman dapat berhasil. NPD yang menyatakan bahwa: ${ }^{27}$

1. The free democratic basic order concept of "abolishing" (beseitigen) describes the abolition of at least one of the constituent elements of the free democratic basic order or its replacement with another constitutional order or another system of government. The

27 Ibid 
criterion "undermining" can be assumed to be a political party, according to its political concept, noticeably threatening the free democratic basic order with sufficient intensity.

2. The fact that a political party is seeking to abstain or undermine the free democratic basic order must be clear from its behavior.

a) The political party is the embodiment of what a party intends to achieve politically.

b) Adherents in this sense are all persons who support their party's cause and profess to the party, even if they are not members of the political party.

c) Activities of political party's organs, specifically the party's executive committee and its leading functionaries, can generally be attributed to the political party. Statements or actions by ordinary members can only be attributed to the political party if they are engaged in a political context and the political party has approved or condoned them. In the case of adherents who are not members of the political party, influence or approval, in whatever form, of their behavior by the political party is generally a necessary condition for attributing such behavior to the party. There can be no blanket attribution of criminal offenses and acts of violence if there is no specific link for such an attribution. No differing assessment may be inferred from the principle of indemnity."

Berdasarkan ukuran yang telah ditentukan sebagaimana terdapat dalam pertimbangan putusan NPD, majelis hakim berpendapat bahwa tidak ada indikasi khusus dan berbobot yang menunjukkan atau setidaknya terdapat kemungkinan bahwa aktivitas yang dilakukan oleh pengurus partai maupun anggota partai NPD dapat berhasil dalam menggangu tatanan demokrasi yang bebas maupun yang membahayakan eksistensi negara federal Jerman, sebagaimana termuat dalam putusan sebagai berikut:

a) The respondent seeks, by reason of its aims and the behaviour of its adherents, to abolish the free democratic basic order. The respondent intends to replace the existing constitutional system with an authoritarian national state that adheres to the idea of an ethnically defined "people's community" (volksgemeinschaft). This political consept disregards the human dignity of all those who do not belong to its ethnically-defined volksgemeinschaft and is thus incompatible with the principle of democracy as set out in the basic law.

b) The respondent advocates aims which are directes against the free democratic basic order and systematically acts towards achieving those aims in a qualified manner.

c) However, there are no specific and weighty indications suggesting even at least the possibility that these endeavours might be successful."

Dengan alasan sebagaimana tersebut, Bundesverfassungsgericht dalam putusannya menyatakan bahwa, the applications of the applicant are rejected as unfounded. Oleh karena itu, terhadap partai NPD dinyatakan sah sebagai partai politik dan dapat kembali menjalankan aktivitasnya sebagaimana yang terdapat pada basic law mengenai jaminan dan perlindungan terhadap partai politik.

Lain halnya dengan pembubaran partai politik di Korea Selatan, MK Korea memiliki beberapa kewenangan, yaitu (i) Pengujian Undang-undang, (ii) pengaduan konstitutional, (iii) penyelesaian sengketa kewenangan, (iv) pemakzulan, dan (v) pembubaran partai politik. Seluruh kewenangan tersebut pernah dilakukan oleh MK Korea. ${ }^{28}$ Tiga kewenangan yang disebutkan diawal merupakan kewenangan yang menjadi "kegiatan rutin" dari MK. Sedangkan dalam hal pemakzulan, MK Korea pernah mengadili upaya pemakzulan Presiden Roh Moo-Hyun pada tahun 2004. Putusan MK berpendirian bahwa tuduhan adanya kecurangan dalam pemilu Presiden tidak cukup mendasar

28 Pasal 111 Konstitusi Korea Selatan: "(1) The Constitutional Court is competent to adjudicate the following matters: (1) The unconstitutionality of law upon the request of the courts; (2) Impeachment; (3) Dissolution of a political party; (4) Disputes about the jurisdictions between State agencies, between State agencies and local governments, and between local governments, and (5) Petitions relating to the Constitution as prescribed by law." 
dan signifikan untuk melucuti jabatan Presiden sehingga kursi kepresidenan tetap dipegang oleh Roh Moo-Hyun. Dan yang paling mutakhir adalah dijalankannya kewenangan pembubaran partai politik ketika MK mengadili kasus dugaan Unified Progressive Party (UPP) menjalankan aktivitas yang bertentangan dengan nilai-nilai fundamental negara pada Desember 2014..$^{29}$ Dengan demikian, sejak berdirinya pada tahun 1988, MK Korea telah mempraktekkan seluruh kewenangan yang dimilikinya.

Alasan konstitusional pembubaran partai politik diatur dalam Pasal 8 (4) Konstitusi Korea yaitu bila tujuan dan kegiatan partai politik bertentangan dengan tertib demokrasi yang mendasar (fundamental democratic order). ${ }^{30}$ Namun, majelis hakim juga mempertimbangkan asas proporsionalitas yaitu perlunya pembatasan kewenangan negara agar tidak bertindak sewenangwenang disertai dengan pertimbangan bahwa pembubaran partai politik itu merupakan langkah terakhir yang bisa dilakukan negara atau terdapat upaya kompromistis lainya yang dapat ditempuh. Dengan demikian, alasan yang diatur dalam Pasal 8 (4) Konstitusi tidaklah bersifat mutlak. Sekiranya partai politik melanggar Pasal 8 (4) Konstitusi, majelis hakim juga perlu mempertimbangkan asas proporsionalitas dimaksud agar tidak terjadi kesewenang-wenangan oleh negara.

Ketika akan mempertimbangkan alasan pembubaran partai politik, majelis hakim terlebih dahulu menafsirkan pasal 8(4) Konstitusi dengan menguraikan setiap frasa yang terkandung dalam pasal tersebut untuk digunakan sebagai alat pengukur. Pertama, majelis hakim menafsirkan makna dari frasa "tujuan dan kegiatan partai politik", kemudian frasa "bertentangan dengan", dan terakhir frasa "tertib demokrasi yang mendasar". Kata "tujuan dan kegiatan partai politik" tidak hanya mengacu pada platform partai yang tercantum dalam Anggaran Dasar/Anggaran Rumah Tangga (AD/ART). Majelis hakim perlu menggali hal-hal lainnya dan tidak hanya

29 Bisariyadi, Cerai Berai Partai di Korea, Majalah Konstitusi No. 118, edisi (Desember 2016), 4

30 Pasal 8 ayat 4 Konstitusi Korea Selatan: "If the purposes or activities of a political party are contrary to the fundamental democratic order, the Government may bring action against it in the Constitutional Court for its dissolution, and, the political party is dissolved in accordance with the decision of the Constitutional Court." menilai dari apa yang tertulis dalam dokumen partai, misalnya dengan melihat publikasi dan bahan-bahan kampanye atau propaganda yang diterbitkan, penyataan resmi partai atau pejabat tingginya dan sebagainya sehingga majelis dapat memahami apa yang tersembunyi dibalik berkas hitam diatas putih. Sedangkan kata "bertentangan dengan" tidak cukup hanya dimaknai dengan pelanggaran ringan melainkan perlu ada bukti kuat yang meyakinkan bahwa tujuan dan kegiatan partai berpotensi untuk menimbulkan bahaya yang bersifat nyata di masa yang akan datang, bahaya yang mengancam kehidupan bernegara. Terakhir, yang dimaksud dengan "tertib demokrasi yang mendasar" adalah unsur-unsur penting yang terkandung dalam nilai-nilai konstitusi seperti: kedaulatan ditangan rakyat, perlindungan terhadap hak warga negara, pemisahan kekuasaan dan sistem multi partai.

Dengan menggunakan ketiga parameter diatas, majelis hakim menelisik bukti-bukti yang disajikan untuk mempertimbangkan adanya pelanggaran konstitusional yang dilakukan Unified Progressive Party (UPP). ${ }^{31}$ Ideologi partai yang tercantum dalam platform UPP disebut dengan "demokrasi progresif". Oleh karenanya, majelis hakim meneliti maksud dari ideologi ini. Berdasarkan bukti-bukti dalam persidangan terbukti bahwa upaya untuk mencapai demokrasi progresif adalah melalui kemandirian (Jaju),

31 UPP sendiri merupakan partai politik ditingkat nasional yang tidak terlalu besar, hanya menduduki 13 kursi di parlemen dari total 300 kursi yang tersedia. Namun demikian, UPP memang dikenal sebagai partai oposisi yang berbeda pendapat dengan kebijakan pemerintah. Bahkan pada tahun 2013, salah satu anggota parlemen dari UPP didak UPP sendiri merupakan partai politik ditingkat nasional yang tidak terlalu besar, hanya menduduki 13 kursi di parlemen dari total 300 kursi yang tersedia. Namun demikian, UPP memang dikenal sebagai partai oposisi yang berbeda pendapat dengan kebijakan pemerintah. Bahkan pada tahun 2013, salah satu anggota parlemen dari UPP didakwa terlibat dalam rencana pemberontakan terhadap pemerintah dengan mendirikan organisasi bawah tanah yang disebut dengan "organisasi revolusioner". Hyun Lee. The Erosion of Democracy in South Korea: The Dissolution of the Unified Progressive Party (UPP) and the Incarceration of Rep. Lee Seok-ki. Dalam http://www.globalresearch. $\mathrm{ca} /$ the-erosion-of-democracy-in-south-korea-thedissolution-of-the-unified-progressive-party-uppand-the-incarceration-of-rep-lee-seok-ki/5421925, diakses pada 8 Oktober 2019 
demokrasi (Minju), dan persatuan nasional (Tongil). Untuk mencapainya, partai harus bertarung dalam pemilihan umum dan bilamana perlu melalui cara-cara dengan menghalalkan kekerasan. Selain itu, peratuan nasional yang dimaksud adalah persatuan antara Korea Selatan dan Korea Utara. Majelis hakim menemukan bahwa ideologi yang dibangun partai adalah sejalan dengan strategi untuk menanamkan ideologi yang dilakukan Korea Utara. Pada saat yang sama, UPP mengakui kedaulatan Korea Utara dan meminggirkan legitimasi kekuasaan Korea Selatan. Ditambah lagi kegiatan-kegiatan partai yang mengarah pada rencana pemberontakan sebagai dasar pertimbangan hakim membubarkan UPP, seperti adanya kekerasan dalam rapat dewan pimpinan pusat, kecurangan dalam pemilu yang dilakukan melalui propaganda maupun kecurangan dalam proses penghitungan suara serta rapat-rapat pimpinan yang digelar dengan agenda rencana pemberontakan. Oleh karenanya, mayoritas majelis hakim berpendirian bahwa UPP melanggar pasal 8(4) konstitusi Korea.

Langkah berikutnya, bukti bahwa UPP melanggar konstitusi tidaklah cukup. Majelis hakim perlu juga mempertimbangkan asas proporsionalitas soal adakah cara lain yang lebih kompromistis dan menguntungkan semua pihak dibandingkan harus membubarkan partai. Majelis hakim memutuskan bahwa situasi politik saat ini dimana Korea Selatan sedang berkonfrontasi dengan Korea Utara membuat tindakan UPP yang berafiliasi dengan Korea Utara mengancam kehidupan bernegara dan hal ini tergolong pada pelanggaran konstitusional yang serius. Upaya untuk memidanakan anggota-anggota partai tidaklah cukup signifikan sehingga pembubaran partai politik dianggap penting untuk mencabut pelanggaran yang potensial atau telah terjadi dari akarnya. Dengan mempertimbangkan bahwa tidak ada cara lain yang dapat dijadikan alternatif maka putusan untuk membubarkan UPP merupakan langkah yang perlu diambil.

\section{Organisasi Sayap Partai Politik dan Hak Partai Politik sebagai Subyek Hukum}

Apabila merujuk kepada Pasal 12 huruf ' $J$ ' UU No. 2 Tahun 2008 yang menyinggung tentang organisasi sayap parpol menentukan: "Partai Politik berhak: a. ...., j. membentuk dan memiliki organisasi sayap Partai Politik; dan, k. ....".
Hal yang kemudian menjadi pertanyaan adalah, apakah organisasi sayap partai politik merupakan badan hukum seperti halnya partai politik sebagai organisasi induknya. Hal ini penting untuk dijawab terlebih dahulu, mengingat organisasi sayap partai politik juga memiliki struktur, kepengurusan, termasuk program kerja, seperti halnya partai politik. Organisasi sayap merupakan bagian dari struktur kepartaian. Secara konseptual, keberadaan organisasi sayap dalam struktur kepartaian dianggap dapat mengurangi beban dan tugas-tugas partai. Terlebih lagi organisasi sayap memiliki karakteristik yang fleksibel sehingga dapat mendiversifikasi daya tarik terlepas dari karakteristik dan tawaran-tawaran ideologis partai terhadap basis dukungan tradisionalnya. ${ }^{32}$

Menurut Ralph Turner dan Lewin Killian, gerakan sosial (social movement) dapat dibagi menjadi tiga kategori. Kategori pertama adalah gerakan yang berorientasi nilai (value-oriented movement). Kategori ini dicirikan dengan komitmen para anggotanya terhadap suatu prinsip yakni menolak segala bentuk kompromi demi satu tujuan yang dicita-citakan. Kategori kedua adalah gerakan yang berorientasi pada kekuasaan (poweroriented movement) yang tujuan utamanya adalah mendapatkan kekuasaan, status, dan pengakuan bagi para anggota gerakan tersebut. Kategori ketiga adalah gerakan yang berorientasi pada partisipasi (participation-oriented movement) yang hanya menyuarakan adanya kekurangan dalam masyarakat, tetapi tidak berusaha aktif menghilangkan kekurangan tersebut. ${ }^{33}$

Ahmad Asroni dkk., mengkategorikan organisasi sayap parpol berdasarkan kategori gerakan menurut Ralph Turner dan Lewin Killian di atas dalam jenis gerakan kedua, yakni gerakan yang berorientasi pada kekuasaan (poweroriented movement) yang tujuan utamanya adalah mendapatkan kekuasaan, status, dan pengakuan bagi para anggota gerakan tersebut. ${ }^{34} \mathrm{Hal}$ ini menunjukan bahwa sebagai sebuah gerakan sosial, organisasi sayap parpol sejatinya sama dengan partai politik, karena gerakan keduanya sama-

\footnotetext{
32 Ahmad Asroni, Muhammad Yusup, dan Adib Sofia, Dakwah Dan Politik: Menakar Kontribusi... op. cit. 29.

33 Ralp Turner \& Lewis Killian, Collective Behavior, Prentice Hall, (New York: New York University Press, 1957), 119 
sama berorientasi atau bertujuan untuk merebut kekuasaan. Akan tetapi terhadap keduanya memiliki perbedaan yang prinsip. Partrai politik merupakan badan hukum (rechtspersoon). Kedudukan partai politik sebagai badan hukum penting bagi partai politik dalam lalu lintas hukum. Bahkan UU Parpol sendiri mengharuskan partai politik untuk mendaftar sebagai badan hukum. ${ }^{35}$ Hal di atas sejalan dengan apa yang dikemukakan oleh Jimly Asshiddiqie, dengan mengutip Article 2 Clause 1 Undang-Undang tentang Partai Politik Jerman mengemukakan, partai politik adalah asosiasi warga negara dan karena itu dapat berstatus sebagai badan hukum (rechts persoon). Akan tetapi, sebagai badan hukum, partai politik itu tidak dapat beranggotakan badan hukum yang lain. Yang hanya dapat menjadi angota badan hukum partai politik adalah perorangan warga negara sebagai natuurlijke persoons. ${ }^{36}$

Uraian di atas menegaskan 2 (dua) hal: Pertama, organisasi sayap partai politik bukan badan hukum, karena yang boleh menjadi anggota partai politik hanyalah manusia sebagai natuurlijke persoons, dan yang berstatus sebagai badan hukum hanyalah partai politik selaku induk organisasi sayap parpol; Kedua, membentuk dan memiliki organisasi sayap partai politik merupakan hak dari partai politik, karena partai politik itu sendiri merupakan pengejawantahan dari hak untuk berkumpul, berserikat, dan mengeluarkan pendapat, maka membentuk dan memiliki organisasi sayap parpol adalah bentuk lain dari hak untuk berkumpul, berserikat, dan mengeluarkan pendapat. Berdasarkan konstruksi di atas, maka dapat juga ditarik kesimpulan bahwa hubungan antara Partai Politik dengan Organisasi Sayap Partai adalah hubungan hukum dalam satu entitas hukum (subyek hukum) yang sama. Dalam konteks ini, Organisasi Sayap Partai Politik merupakan organisasi bukan badan hukum yang berada di bawah (dalam struktur) dan milik Partai Politik sebagai badan hukum (rectshpersoon). Hubungan antara keduanya bersifat internal dan struktural. Dikatakan bersifat internal karena organisasi sayap parpol tidak berbadan hukum,

35 Pasal 3 ayat (1) Undang-Undang Nomor 2 Tahun 2008 tentang Partai Politik, Lembaran Negara Republik Indonesia Tahun 2008, Nomor 2, Tambahan Lembaran Negara Nomor 4801.

36 Jimly Asshiddiqie, Kemerdekaan Berserikat, Pembuabaran Partai Politik Dan Mahkamah Konstitusi......Op.Cit., 69. melainkan organisasi bukan yang dibentuk oleh partai politik sebagai badan hukum. Dikatakan bersifat struktural, karena organisasi sayap parpol berada dibawah Partai Politik yang membentuknya.

\section{Larangan dan Sanksi bagi Partai Politik}

Pada bagian sebelumnya, telah diuraikan bahwa hubungan antara Partai Politik dan Organisasi Sayap Parpol adalah bersifat internal dan struktural, karena Organisasi Sayap Parpol itu sendiri memang di bentuk oleh Partai Politik, namun di saat yang bersamaan, UU Parpol juga mengatur larangan dan sanksi bagi Partai Politik dalam Pasal 40 dan Pasal 48 UU No. 2 Tahun 2008. Adapaun larangan terhadap Partai Politik terdiri atas: ${ }^{37}$

(1) Partai Politik dilarang menggunakan nama, lambang, atau tanda gambar yang sama dengan:
a. bendera atau lambang negara Republik Indonesia;
b. lambang lembaga negara atau lambang Pemerintah;
c. nama, bendera, lambang negara lain atau lembaga/badan internasional;
d. nama, bendera, simbol organisasi gerakan separatis atau organisasi terlarang;
e. nama atau gambar seseorang; atau yang mempunyai persamaan pada pokoknya atau keseluruhannya dengan nama, lambang, atau tanda gambar Partai Politik lain.

(2) Partai Politik dilarang:

a. melakukan kegiatan yang bertentangan dengan Undang-undang Dasar Negara Republik Indonesia Tahun 1945 dan peraturan perundangundangan; atau,
b. melakukan kegiatan yang membahayakan keutuhan dan keselamatan Negara Kesatuan Republik Indonesia.

(3) Partai Politik dilarang:

\footnotetext{
37 Pasal 40 Undang-Undang No 2 Tahun 2008 tentang Partai Politik, Lembaran Negara Republik Indonesia Tahun 2008, Nomor 2, Tambahan Lembaran Negara Nomor 4801.
} 
a. menerima dari atau memberikan kepada pihak asing sumbangan dalam bentuk apa pun yang bertentangan dengan peraturan perundang-undangan;

b. menerima sumbangan berupa uang, barang, ataupun jasa dari pihak mana pun tanpa mencantumkan identitas yang jelas; menerima sumbangan dari perseorangan dan/atau perusahaan/ badan usaha melebihi batas yang ditetapkan dalam peraturan perundangundangan;

c. meminta atau menerima dana dari badan usaha milik negara, badan usaha milik daerah, dan badan usaha milik desa atau dengan sebutan lainnya; atau

d. menggunakan fraksi di Majelis Permusyawaratan Rakyat, Dewan Perwakilan Rakyat, Dewan Perwakilan Rakyat Daerah Provinsi, dan Dewan Perwakilan Rakyat Daerah Kabupaten/ Kota sebagai sumber pendanaan Partai Politik.

(4) Partai Politik dilarang mendirikan badan usaha dan/atau memiliki saham suatu badan usaha.

(5) Partai Politik dilarang menganut dan mengembangkan serta menyebarkan ajaran atau paham komunisme/MarxismeLeninisme.

Terhadap Partai Politik yang melanggar larangan sebagaimana diuraikan di atas, maka akan dikenakan sanksi administratif yang terdiri atas: ${ }^{38}$ (1) penolakan pendaftaran Partai Politik sebagai badan hukum oleh Departemen; (2) teguran oleh Pemerintah; (3) penghentian bantuan Anggaran Pendapatan dan Belanja Negara/ Anggaran Pendapatan dan Belanja Daerah; teguran oleh Komisi Pemilihan Umum; (4) sanksi administratif yang ditetapkan oleh badan/lembaga yang bertugas untuk menjaga kehormatan dan martabat Partai Politik beserta anggotanya; (5) pembekuan kepengurusan oleh pengadilan negeri; (6) dibubarkan dengan Putusan Mahkamah Konstitusi.

38 Pasal 47 dan Pasal 48 ayat (1), (2) dan ayat (3) Undang-Undang No 2 Tahun 2008 tentang Partai Politik, Lembaran Negara Republik Indonesia Tahun 2008, Nomor 2, Tambahan Lembaran Negara Nomor 4801.
Terhadap Partai Politik yang melanggar larangan sebagaimana diuraikan di atas, maka akan dikenakan sanksi pidana yang terdiri atas:

(1) Pidana Penjara bagi pengurus Partai Politk;

(2) Pidana Denda bagi pengurus Partai Politik;

(3) Penyitaan Aset dan Saham bagi Negara; (4) Pidana Penjara bagi Orang atau Badan Usaha yang memberikan sumbangan melebihi ketentuan;

(5) Pidana Denda dua kali lipat dari yang disumbangkan, bagi Orang atau Badan Usaha yang memberikan sumbangan melebihi ketentuan; (6) Penyitaan terhadap kelebihan sumbangan.

Melihat pada jenis pelanggaran dan sanksi bagi sebuah Parpol di atas, diharapkan dapat menciptakan kehidupan iklim demokrasi di Indonesia yang sesuai dengan prinsip negara hukum yang demokratis atau negara demokratis yang berdasarkan hukum.

\section{E. Pelanggaran Organisasi Sayap Partai Politik terhadap Larangan dalam Pasal 40 UU Parpol dan Implikasinya terhadap Partai Politik}

Sebagaimana telah di uraikan pada bagian sebelumnya, bahwa Organisasi Partai Politik bukan merupakan badan hukum. Meskipun demikian, jika melihat pada Undang-Undang Nomor 17 Tahun 2013 tentang Organisasi Kemasyarakat, Organisasi Sayap Partai Politik dapat dipadankan dengan Organisasi Kemasyarakatan bukan berbadan hukum. ${ }^{39}$ Akan tetapi menyamakan Organisasi Sayap Parpol dengan organisasi bukan berbadan hukum sebagaimana dimaksud dalam Pasal 10 UU Ormas, adalah tidak sepenuhnya benar. Hal tersebut dikarenakan, Ormas bukan badan hukum yang dimaksud dalam UU Ormas, adalah sebuah organisasi yang mandiri, yang dibentuk langsung oleh warga negara Indonesia, minimal 3 (tiga) orang atau lebih. ${ }^{40}$ Ormas, baik yang berbadan hukum maupun bukan berbadan hukum, merupakan pengejawantahan dari hak asasi manusia yang diatur dalam konstitusi. UUD 1945 secara langsung dan tegas memberikan jaminan kebebasan untuk berserikat atau berorganisasi (freedom of association), kebebasan

39 Dalam Pasal 10 ayat (1) Undang-Undang Nomor 17 Tahun 2013 tentang Organisasi Kemasyarakatan ditentukan: "Ormas sebagaimana dimaksud dalam Pasal 9 dapat berbentuk: a. badan hukum; atau, $b$. tidak berbadan hukum.

$40 \quad$ Pasal 9 Undang-Undang Nomor 17 Tahun 2013 tentang Organisasi Kemasyarakatan. 
berkumpul (freedom of assembly), dan kebebasan menyatakan pendapat (freedom of expression) ${ }^{41}$

Sedangkan Organisasi Sayap Parpol merupakan hak dari Partai Politik yang dibentuk sebagai pengejawantahan kebebasan untuk berserikat atau berorganisasi (freedom of association), kebebasan berkumpul (freedom of assembly), dan kebebasan menyatakan pendapat (freedom of expression). Dengan demikian, Organisasi Sayap Parpol adalah hak yang timbul kemudian setelah hak kebebasan berkumpul, berserikat, dan menyatakan pendapat, diwujudkan dalam Partai Politik. Artinya, Organisasi Sayap Parpol tidak sepenuhnya dibentuk berdasarkan hak kebebasan berkumpul, berserikat, dan menyatakan pendapat, melainkan hak yang lahir kemudian. Sehingga membentuk Organisasi Sayap Parpol tidak bisa dikatengorikan sebagai natural rights yang bersifat fundamental dan melekat dalam peri kehidupan bersama umat manusia. Yang merupakan natural rights adalah Partai Politik sebagai induk dari Organisasi Sayap Parpol.

Sebagaimana diuraikan pada bagian sebelumnya, meminjam pendekatan Ralph Turner dan Lewin Killian, maka Organisasi Sayap Parpol dapat dikategorikan sebagai gerakan yang berorientasi pada kekuasaan (poweroriented movement) yang tujuan utamanya adalah mendapatkan kekuasaan, status, dan pengakuan bagi para anggota gerakan tersebut. Dalam kategori yang demikian, maka Organisasi Sayap Parpol sejatinya memiliki potensi dan kemampuan untuk melanggar larangan yang ditentukan dalam Pasal 40 UU No. 2 Tahun 2008. Hal dikarenakan, organisasi sayap partai politik mempunyai struktur sebagai sebuah organisasi yang hampir sama dengan partai politik selaku organisasi induknya.

Akan tetapi yang menjadi persoalan kemudian, UU Parpol tidak mengatur apabila Organisasi Sayap Parpol melakukan perbuatan atau kegiatan sebagaimana yang dilarang dalam Pasal 40 UU Parpol. Jika mengacu pada UU Ormas, maka Ormas bukan berbadan hukum dapat dijatuhi sanksi administratif yang meliputi:

(a) peringatan tertulis; (b) penghentian bantuan dan/atau dana hibah; (c) Penghentian sementara kegiatan; dan, (d) pencabutan surat keterangan

41 Anonim, Naskah Akademik Rancangan UndangUndang Tentang Perkumpulan, Kementerian Hukum Dan Hak Asasi Manusia RI, Badan Pembinaan Hukum Nasional Tahun 2016, 9. terdaftar. $^{42}$ Akan tetapi sebagaimana telah dikemukakan sebelumnya, bahwa Organisasi Sayap Parpol tidak sepenuhnya sama dengan Ormas bukan badan hukum, sehingga ketentuan dalam UU Ormas tidak bisa diberlakukan sertamerta bagi Organisasi Saya Parpol.

Sebenarnya jika melihat pada kedudukan Organisasi Sayap Parpol, maka mekanisme yang tepat bagi Organisasi Sayap Parpol, adalah sama dengan mekanisme yang berlaku bagi Partai Politik itu sendiri. Hal ini sebagaimana disinggung di atas, Organisasi Sayap Parpol adalah hak yang timbul kemudian setelah hak kebebasan berkumpul, berserikat, dan menyatakan pendapat, diwujudkan dalam Partai Politik. Sehingga ketika Organisasi Sayap Parpol melakukan pelanggaran sebagaimana yang diatur dalam Pasal 40 UU Partai Politik, maka mekanisme dan sanksi yang berlaku adalah sebagaimana diatur dalam Pasal 47, 48, sampai dengan Pasal 49 UU No. 2 Tahun 2008.

Terhadap pelanggaran yang dikenakan sanksi administratif selain Pembubaran Partai Politik, maka Organisasi Sayap Partai bertangungjawab sebagai organisasi tanpa melibatkan Partai Politik selaku organisasi induknya. Akan tetapi terhadap pelanggaran yang sanksinya adalah Pembubaran Partai Politik, maka pelanggaran yang dilakukan oleh Organisasi Sayap Parpol dapat menjadi alat bukti dalam pembubaran Parpol di Mahkamah Konstitusi.

\section{F. Pertanggungjawaban dari Segi Hukum Organisasi Sayap Partai Politik}

Pertanggungjawaban hukum dalam hal ini tidak dapat dilepaskan dari bentuk hukum organisasi sayap partai politik serta tindakan hukum yang dilakukan oleh organisasi sayap partai politik. Dengan demikian, ada beberapa isu hukum yang beririsan dengan pertanggungjawaban hukum organisasi sayap partai politik. Akan tetapi, pada tulisan ini hanya akan diambil dua pertanggungjawaban hukum Organisasi Sayap Partai Politik. Pertama, pertanggungjawaban hukum organisasi sayap partai politik yang beririsan dengan tindak pidana korupsi. ${ }^{43}$ Kedua, pertanggungjawaban hukum organisasi sayap partai

\footnotetext{
42 Pasal 61 Undang- Undang Nomor 17 Tahun 2013 tentang Organisasi Kemasyarakatan

43 Eddy O.S. Hiariej, Prinsip-Prinsip Hukum Pidana, (Yogyakarta, Cahaya Atma Pustaka, 2018), 17.
} 
politik yang beririsan dengan pelanggaran yang diatur dalam UU Partai Politik. Konstruksi hukum Pasal 1 UU No. 31 Tahun 1999 menempatkan korporasi sebagai subjek hukum yang dapat dikenakan pemidanaan. Setiap orang adalah perseorangan (naturlijkepersoon) atau termasuk korporasi (rechtpersoon)?. ${ }^{44}$ Sedangkan korporasi adalah kumpulan orang dan/atau kekayaan yang terorganisasi baik merupakan badan hukum maupun bukan badan hukum. ${ }^{45}$

Mengacu ke ketentuan tentang kumpulan orang yang terorganisasi, maka Pasal 1 angka 1 UU No. 16 Tahun 2017 serta penjelasan Pasal 12 huruf j UU No. 2 Tahun 2008 dapat dijadikan acuan untuk menempatkan organisasi sayap partai politik sebagai korporasi. Organisasi sayap partai politik berisi sekumpulan orang yang terorganisasi baik berbadan hukum (perkumpulan atau yayasan) maupun bukan berbadan hukum (mendapatkan Surat Keterangan Terdaftar atau Pendataan) yang menjadi unsur dari korporasi sebagaimana dimaksud dalam Pasal 1 ayat (1) UU No. 31 Tahun 1999 sehingga organisasi sayap partai politik dapat dibebani pertanggungjawaban hukum tindak pidana korupsi.$^{46}$ Ketentuan tentang pembebanan pertanggungjawaban hukum tindak pidana korupsi ke korporasi diatur dalam Pasal 20 UU No. 31 Tahun 1999. Dalam pasal tersebut dapat dirangkum ketentuan pembebanan pertanggungjawaban hukum tindak pidana korupsi sebagai berikut: (1) Dalam hal korupsi dilakukan oleh atau atas nama korporasi, maka tuntutan pidana dapat dilakukan terhadap korporasi dan/atau pengurusnya; ${ }^{47}$ (2) Korupsi dilakukan oleh korporasi apabila korupsi tersebut dilakukan oleh orang baik berdasarkan hubungan kerja maupun berdasarkan hubungan lain, bertindak dalam lingkungan korporasi baik sendiri-sendiri maupun bersama-sama; ${ }^{48}$ dan (3) Tuntutan pidana terhadap korporasi yang melakukan korupsi, maka korporasi tersebut diwakili oleh pengurusnya. ${ }^{49}$

Berdasarkan norma sebagaimana diatur dalam Pasal 20 UU No. 31 Tahun 1999 yang dihubungkan dengan penjelasan Pasal 12 huruf j UU No. 2 Tahun 2008, maka akan diperoleh variasi kemungkinan relasi pertanggungjawaban hukum organisasi sayap partai politik dan partai politik dalam dugaan tindak pidana korupsi. Relasi tersebut ditunjukkan dengan tabel di bawah ini:

Tabel 1. Probabilitas Beban Pertanggung Jawaban Hukum Organisasi Sayap Politik ${ }^{50}$

\begin{tabular}{|c|c|c|}
\hline \multicolumn{3}{|c|}{ Ketentuan } \\
\hline \multicolumn{3}{|c|}{$\begin{array}{l}\text { Organisasi sayap Partai Politik merupakan organisasi yang } \\
\text { dibentuk oleh dan/atau menyatakan diri sebagai sayap partai } \\
\text { politik sesuai dengan AD dan ART masing-masing Partai } \\
\text { Politik (Penjelasan Pasal } 12 \text { huruf j UU No. } 2 \text { Tahun 2008) }\end{array}$} \\
\hline No & Pertanggungjawaban Hukum & $\begin{array}{l}\text { Kemungkinan } \\
\text { Pembebanan }\end{array}$ \\
\hline 1. & $\begin{array}{l}\text { Pengurus organisasi sayap } \\
\text { partai politik diduga } \\
\text { melakukan korupsi }\end{array}$ & Pengurus \\
\hline 2. & $\begin{array}{l}\text { Pengurus organisasi sayap } \\
\text { partai politik diduga } \\
\text { melakukan korupsi }\end{array}$ & $\begin{array}{l}\text { Organisasi sayap partai } \\
\text { politik }\end{array}$ \\
\hline 3. & $\begin{array}{l}\text { Pengurus organisasi sayap } \\
\text { partai politik diduga } \\
\text { melakukan korupsi }\end{array}$ & Pengurus dan organisasi \\
\hline 4. & \begin{tabular}{|l|} 
Pengurus organisasi sayap \\
partai politik diduga \\
melakukan korupsi yang \\
berkaitan dengan partai politik
\end{tabular} & Pengurus \\
\hline 5. & $\begin{array}{l}\text { Pengurus organisasi sayap } \\
\text { partai politik diduga } \\
\text { melakukan korupsi yang } \\
\text { berkaitan dengan partai politik }\end{array}$ & $\begin{array}{l}\text { Organisasi sayap partai } \\
\text { politik }\end{array}$ \\
\hline 6. & $\begin{array}{l}\text { Pengurus organisasi sayap } \\
\text { partai politik diduga } \\
\text { melakukan korupsi yang } \\
\text { berkaitan dengan partai politik }\end{array}$ & Pengurus dan organisasi \\
\hline 7. & \begin{tabular}{|l|} 
Pengurus organisasi sayap \\
partai politik diduga \\
melakukan korupsi yang \\
berkaitan dengan partai politik
\end{tabular} & Partai Politik \\
\hline 8. & $\begin{array}{l}\text { Pengurus organisasi sayap } \\
\text { partai politik diduga } \\
\text { melakukan korupsi yang } \\
\text { berkaitan dengan partai politik }\end{array}$ & $\begin{array}{l}\text { Pengurus, organisasi } \\
\text { sayap partai politik, dan } \\
\text { partai politik }\end{array}$ \\
\hline
\end{tabular}

$50 \quad$ Hifdzil Alim, Pengaturan Organisasi Sayap Partai Politik: Bentuk, Relasi, Dan Pertanggungjawaban Hukum, makalah disampaikan dalam Simposium Hukum Tata Negara, di Fakultas Hukum Universitas Islam Indonesia Tanggal 30 Juni 2019, 12 
Jenis pelanggaran yang dikenakan ke partai politik (khususnya terkait kewajiban yang tidak dilaksanakan oleh partai politik) dapat diterapkan ke organisasi sayap partai politik. Sesuai dengan norma Bab XIX tentang Sanksi yang diatur dalam UU No. 2 Tahun 2008 jo UU No. 2 Tahun 2011, maka Organisasi Sayap Partai Politik dapat dikenakan pertanggungjawaban hukum dengan pengecualian tertentu sebagai berikut:

(1) organisasi sayap partai politik yang tidak memenuhi syarat administrasi pendirian dikenakan sanksi administratif berupa penolakan pendaftaran sebagai badan hukum; dan (2) organisasi sayap partai politik yang tidak membuat dan memelihara daftar penyumbang dikenai sanksi administratif berupa teguran oleh pemerintah.

Pada pokoknya, beberapa ketentuan pertanggungjawaban hukum untuk partai politik yang diatur dalam UU Partai Politik dapat dikenakan ke organisasi sayap partai politik karena posisi organisasi sayap partai politik yang subordinat dengan partai politik. Tentu saja terdapat pengecualian tertentu terhadap pertanggungjawaban hukum tersebut.

Pengecualian yang dimaksud adalah ketentuan yang diatur oleh peraturan perundang-undangan terhadap hal-hal yang ditentukan hanya dapat dilaksanakan oleh partai politik. ${ }^{51}$

Pengecualian tersebut dapat ditentukan, misalnya, dalam hal fungsi, hak, dan kewajiban. Dalam hal fungsi, partai politik memiliki fungsi melakukan rekrutmen politik dalam proses pengisian jabatan publik.52 Sedangkan organisasi sayap partai politik tidak dapat melakukan rekrutmen individu untuk pengisian jabatan publik. Sebagai contoh, jabatan publik untuk Presiden dan Wakil Presiden diusulkan oleh partai politik. ${ }^{53}$ Demikian juga untuk anggota DPR, DPRD Provinsi dan DPRD Kabupaten/Kota. ${ }^{54}$ Organisasi sayap partai politik tidak dapat melakukan perekrutan untuk jabatan-jabatan tersebut. Selain fungsi rekrutmen individu untuk jabatan publik, organisasi sayap partai politik dapat melakukan fungsi partai politik

51 Ali Marwan HSB, Mengkritisi Pemberlakuan Teori Fiksi Hukum, Jurnal Penelitian Hukum De Jure 16, No. 3, (2016), 252

52 Pasal 11 ayat (1) huruf e UU No. 2 Tahun 2008.

53 Pasal 6A ayat (2) UUD 1945 dan Pasal 1 angka 28 UU No. 7 Tahun 2017 tentang Pemilihan Umum

54 Pasal 67, Pasal 314, dan Pasal 363 UU No. 17 Tahun 2014 tentang MPR, DPR, DPD, dan DPRD lainnya. Semisal fungsi pendidikan politik, fungsi penciptaan iklim yang kondusif bagi persatuan dan kesatuan bangsa, fungsi penyalur aspirasi politik, serta fungsi partisipasi politik warga. ${ }^{55}$

Dalam hal mendapatkan hak, dari sebelas hak yang dimiliki oleh partai politik, dua hak dapat diperoleh oleh organisasi sayap partai politik, satu hak masih dapat diperdebatkan, dan delapan hak tidak boleh dimiliki. ${ }^{56}$ Hak yang dapat diberikan ke organisasi sayap partai politik meliputi dua hak. Pertama, hak mendapatkan perlakuan hukum yang sama. Setiap organisasi sayap partai politik diberi perlakuan yang sama, sederajat, dan adil dari negara. Hal ini berkaitan dengan, contohnya, ketentuan yang sama untuk persyaratan pembentukan. Kedua, hak untuk mendapatkan hak cipta atas nama, lambang, dan tanda gambar organisasi sayap partai politik. Ketentuan mengenai hak cipta memberikan ruang ke setiap badan hukum untuk dapat melakukan klaim atas ciptaannya. organisasi sayap partai politik juga dapat melakukan klaim atas nama, lambang, dan tanda gambar dari organisasi sayap partai politik itu sendiri. ${ }^{57}$

Hak partai politik yang masih diperdebatkan untuk dimiliki oleh organisasi sayap partai politik adalah hak untuk mengatur dan mengurus sendiri rumah tangga organisasi secara mandiri. organisasi sayap partai politik karena ditetapkan sebagai bagian dari partai politik, kemungkinan pengaturan dan pengurusan rumah tangganya akan mengikuti ketentuan pengaturan dan pengurusan dari partai politik yang diikutinya. Misalnya, campur tangan partai politik dalam hal menentukan siapa yang akan menjadi ketua/pengurus organisasi sayap partai politik tidak dapat dielakkan. Alasannya sederhana, tidak boleh berseberangan dengan partai politiknya. Tentu saja siapa yang akan memimpin organisasi sayap partai politik harus mendapatkan restu dari partai politiknya sehingga

55 Mengenai penjelasan setiap fungsi sebagai sarana yang dimiliki oleh partai politik, lihat Pasal 11 ayat (1) huruf a, huruf b, huruf c, dan huruf d UU No. 2 Tahun 2008.

56 Mengenai jenis hak partai politik, lihat Pasal 12 UU No. 2 Tahun 2008.

57 UU No. 28 Tahun 2014 tentang Hak Cipta memberi ruang semua ciptaan dapat dilakukan klaim atasnya. Di dalam Pasal 2 huruf a dinyatakan, "Semua ciptaan dan produk hak terkait dengan warga negara, penduduk, dan badan hukum Indonesia”. 
terdapat kesesuaian arah tujuan politik organisasi sayap partai politik dan partai politiknya. Akan tetapi, pilihan lain dari pengaturan dan pengurusan organisasi sayap partai politik juga dapat diambil dengan batas-batas tertentu. organisasi sayap partai politik dapat menentukan sendiri ketual pengurus organisasi sayap partai politik tanpa campur tangan partai politik, tetapi kesesuaian arah tujuan politik tetap harus mengikuti garis partai politik. Pada bagian ini, terdapat dua lapis hak. Lapis pertama adalah hak untuk menentukan ketua/pengurus organisasi sayap partai politik yang sepenuhnya diserahkan ke organisasi sayap partai politik tanpa campur tangan partai politik. Lapis kedua adalah hak untuk menentukan kesesuaian arah tujuan organisasi sayap partai politik yang harus disamakan dengan arah tujuan partai politiknya. Konsekuensi dari lapis kedua ini adalah partai politik dapat masuk dan campur tangan ke dalam organisasi sayap partai politik untuk menentukan arah dan tujuan organisasi sayap partai politik. Selain hakhak yang telah disebutkan sebelumnya, hak-hak lainnya tidak dapat diberikan ke organisasi sayap partai politik.

\section{KESIMPULAN}

Uraian di atas menunjukan bahwa pengaturan organisasi sayap partai politik memang jauh dari memadai. Padahal sebagai Organisasi Sayap Parpol secara kedudukan dapat dipadankan dengan Ormas tidak berbadan hukum. Dalam UU Ormas juga mengatur tentang larangan dan sanksi bagi Ormas bukan berbadan hukum. Sehingga perlu ada pengaturan berkenaan dengan Organisasi Sayap Parpol, khususnya berkenaan dengan larangan dan sanksi bagai Organisasi Sayap Parpol.

Berdasarkan uraian di atas, maka tulisan ini menarik dua kesimpulan sebagai berikut: Pertama, hubungan hukum antara Organisasi Sayap Partai Politik dan Partai Politik adalah hubungan hukum dalam satu entitas hukum (subyek hukum) yang sama. Dalam konteks ini, Organisasi Sayap Partai Politik merupakan organisasi bukan badan hukum yang berada di bawah (dalam struktur) dan milik Partai Politik sebagai badan hukum (rectshpersoon). Hubungan antara keduanya bersifat internal dan struktural. Dikatakan bersifat internal karena organisasi sayap parpol bukan badan hukum, melainkan organisasi bukan badan hukum yang dibentuk oleh badan hukum partai politik. Dikatakan bersifat struktural, karena organisasi sayap parpol berada dibawah Partai Politik yang membentuknya.

Kedua bahwa kegiatan OSP yang bertentangan dengan UUD 1945 dapat menjadi alasan pembubaran partai politik di Mahkamah Konstitusi. Sehingga ketika OSP melanggar ketentuan yang dilarang sebagaimana yang diatur dalam Pasal 40 UU Partai Politik, maka mekanisme dan sanksi yang berlaku adalah sama dengan mekanisme penjatuhan sanksi sebagaimana diatur dalam Pasal 47, 48 dan 49 UU Partai Politik. Dalam hal ini, terhadap pelanggaran yang dikenakan sanksi administratif selain Pembubaran Partai Politik, OSP bertanggungjawab dalam kedudukannya sebagai organisasi bukan berbadan hukum, dan tanpa melibatkan Partai Politik. Sedangkan terhadap pelanggaran yang sanksinya adalah Pembubaran Partai Politik, maka pelanggaran yang dilakukan oleh OSP dapat menjadi alat bukti dan alasan dalam pembubaran Parpol di Mahkamah Konstitusi.

\section{SARAN}

Saran ditujukan kepada pembentuk undang-undang yang pada pokok-pokoknya penulis merekomendasi untuk merevisi undangundang yang berkaitan dengan partai politik dan Mahkamah Konstitusi yang khususnya berkaitan dengan pembubaran partai politik yang antara lain memuat: Penegasan yang lebih komprehensif hubungan hukum antara OSP dan Partai Politik; Penegasan bahwa larangan sebagaimana dimaksud dalam Pasal 40 UU Partai Politik juga mengikat kepada OSP dan memiliki cakupan sanksi yang sama sebagaimana dalam Pasal 47, 48, dan 49 UU Partai Politik; dan Memasukan ketentuan di dalam UU Mahkamah Konsitusi bahwa alasan pembubaran partai politik tidak hanya kegiatan partai politik yang bertentangan dengan UUD 1945, namun juga termasuk OSP. 


\section{UCAPAN TERIMA KASIH}

Terima kasih diucapkan kepada Lembaga Penelitian dan Pengabdian MasyarakatUMJ (LPPM-UMJ), Pusat Pengkajian dan Pengembangan Ilmu Hukum-UMJ (P3IH-UMJ) atas segala supportnya dalam penyusunan artikel ini.

\section{DAFTAR KEPUSTAKAAN}

Alim, Hifdzil, Pengaturan Organisasi Sayap Partai Politik: Bentuk, Relasi, Dan Pertanggungjawaban Hukum, makalah disampaikan dalam Simposium Hukum Tata Negara, di Fakultas Hukum Universitas Islam Indonesia Tanggal 30 Juni 2019.

Anonim, Naskah Akademik Rancangan UndangUndang Tentang Perkumpulan, Kementerian Hukum Dan Hak Asasi Manusia RI, Badan Pembinaan Hukum Nasional Tahun 2016,

Asroni, Ahmad, Yusup, Muhammad, dan Sofia, Adib. Dakwah Dan Politik: "Menakar Kontribusi Organisasi Islam Sayap Partai Politik Bagi Masyarakat Muslim Yogyakarta", Jurnal Dakwah XIV, no. 1, (2013) 44-60

Asshiddiqie, Jimly. Pokok-Pokok Hukum Tata Negara Indonesia, Jakarta: PT. Bhuana Ilmu Populer, , 2007.

---------omerdekaan Berserikat, Pembuabaran Partai Politik Dan Mahkamah Konstitusi, Jakarta: Konstitusi Press, 2006.

Azed, Abdul Bari dan Amar, Makmur. Pemilu \& Partai Politik Di Indonesia, Jakarta: Pusat Studi Hukum Tata Negara Fakultas Hukum Universitas Indonesia, 2005.

Babbie, Earl, The Practice of Social Research, Belmont: Wadsworth Publising Company, (1998)

Bangun, Budi Hermawan, "Perbandingan Sistem Dan Mekanisme HAM Negara-Negara Anggota ASEAN: Tinjauan Konstitusi Dan Kelembagaan", Jurnal Penelitian HAM 10, No. 1, (2019), 99-114.

Bisariyadi, Cerai Berai Partai di Korea, Majalah Konstitusi No. 118, edisi (Desember 2016)
Budiarjo, Miriam, Pengantar Ilmu Politik, Jakarta: Gramedia, 2000.

Bundesverfassungsgericht, "Headnotes to the Judgement of the Second Senate of 17 January 2017 - 2BvB 1/13 -“, https:// www.bundesverfassungsgericht.de/ SharedDocs/Entscheidungen/EN/2017/01/ bs20170117_2bvb000113en.html,diakses pada tanggal 08 Oktober 2019

Davies, Peter, Derek Lynch, The Routledge Companion To Fascism And The Far Right, Psychology Press, (2002)

Fatah, Eep Saefulloh. Catatan Politik 1998 1999 Eep Saefuloh Fatah; Menuntaskan Perubahan. Jakarta: Mizan, (2000)

Hartono, Sunaryati, Penelitian Hukum Di Indonesia Pada Akhir Abad Ke-20, Bandung: Alumni, (1994)

Hiariej, Eddy O.S., Prinsip-Prinsip Hukum Pidana, Yogyakarta, Cahaya Atma Pustaka, (2018)

Hutabarat, Ramly. Politik Hukum Pemerintahan Soeharto tentang Demokrasi Politik di Indonesia (1971-1997). Disertasi Program Doktor Ilmu Hukum Pascasarjana Universitas Indonesia, (2002)

Juniarto. Sejarah Ketatanegaraan Republik Indonesia, Jakarta: Bumi Aksara, (1984)

Karim, M. Rusli. Perjalanan Partai Politik Di Indonesia; Sebuah potret pasang-surut, Jakarta: Rajawali Press, (1993).

Lee, Hyun The Erosion of Democracy in South Korea: The Dissolution of the Unified Progressive Party (UPP) and the Incarceration of Rep. Lee Seok-ki. Dalam http://www.globalresearch.ca/theerosion-of-democracy-in-south-korea-thedissolution-of-the-unified-progressive-partyupp-and-the-incarceration-of-rep-lee-seokki/5421925, diakses pada 8 Oktober 2019

Liddle, William R., Partisipasi \& Partai Politik Indonesia pada Awal Orde Baru, Jakarta: Pustaka Utama Grafiti, (1992)

Marwan, Ali, "Mengkritisi Pemberlakuan Teori Fiksi Hukum”, Jurnal Penelitian Hukum De Jure 16, No. 3, (2016): 251 - 264 
Puspitasari, Sri Hastuti, Mandasari, Zayanti, Harry Setya Nugraha, "Urgensi Perluasan Permohonan Pembubaran Partai Politik di Indonesia", Jurnal Hukum Ius Quia Iustum 23, No 4 (2016): $552-575$

Turner, Ralp \& Killian, Lewis. Collective Behavior, New York: Prentice Hall, 1957.

Safa'at, Mochamad Ali, Pembubaran Partai Politik Di Indonesia: Analisis Pengaturan Hukum dan Praktik Pembubaran Partai Politik 1959 - 2004, Jakarta: Disertasi FH UI, (2009)

Stokes. S. C., "Political Parties And Democracy", Annual Review Political Science 18, No 2 (1999): 243

Widayati. "Pembubaran Partai Politik Dalam Sistem Ketatanegaraan Indonesia", Jurnal Hukum XXVI, No. 2, (2011), 34-51.

Winata, Muhammad Reza, "Politik Hukum Dan Konstitusionalitas Kewenangan Pembubaran Organisasi Kemasyarakatan Berbadan Hukum Oleh Pemerintah", Jurnal Penelitian Hukum De Jure 18, No. 4, (2018), $445-464$ 